DOI: https://doi.org/10.34069/AI/2021.38.02.14

\title{
Protection of public interests by narrowing private interests: where is the limit?
}

\section{Захист публічних інтересів за рахунок звуження інтересів приватних: де межа?}

Received: February 4, 2021

\section{Abstract}

The coronavirus pandemic (COVID-19) has posed many challenges to the international community. In a pandemic, governments make complex decisions every day (respond quickly to emerging difficulties), implement effective quarantine measures that affect the public and private interests of the people. Such decisions are also made by such supranational entities as the European Union. With this in mind, it is essential to analyze the interaction and balance of private and public interests in EU law in the context of the Covid-19 pandemic. The work aims to analyze the balance between private and public interests in EU law in the context of the Covid19 pandemic. Research methods are such methods as dialectical, historical, idealization, analysis, synthesis, abstraction, system, formalization, comparison, and modeling. As a result of the study, the authors concluded that the search for a balance between public and private interests is in all areas and mostly applies to human rights and, in a pandemic, these powers are enshrined in major international treaties and national regulations, with reservations about their possible limitation under exceptional circumstances. At the same time, ensuring the balance of private and public interests is possible only if the rule of law is fulfilled in the
Accepted: March 5, 2021

$\begin{array}{r}\text { Written by: } \\ \text { Olga Klepikova } \\ 41\end{array}$
https://orcid.org/0000-0001-5166-215X
Viktoriia Kachuriner ${ }^{42}$
https://orcid.org/0000-0003-2553-5071
Volodymyr Makoda ${ }^{43}$
https://orcid.org/0000-0003-4408-1925
Inha Kryvosheyina ${ }^{44}$
https://orcid.org/0000-0003-3630-2257
Vadym Popeliuk ${ }^{45}$
https://orcid.org/0000-0002-7415-3996

\section{Анотація}

Пандемія, спричинена коронавірусною інфекцією (COVID-19) поставила багато викликів перед міжнародною спільнотою. В умовах пандемії уряди країн приймають складні рішення кожного дня (швидко реагувати на нововиявлені труднощі), впроваджувати ефективні карантинні заходи, які впливають на публічні та приватні інтереси людей. Відповідні рішення приймаються i таким наддержавним утворенням, як Свропейський Союз. 3 огляду на це важливо проаналізувати взаємодію та баланс приватних та публічних інтересів в праві СС в умовах пандемії Covid-19. Метою роботи $є$ аналіз дотримання балансу між приватними та публічними інтересами в праві СС в умовах пандеміï Covid-19. Методами дослідження $€$ такі методи як діалектичний, історичний, ідеалізації, аналіз, синтез, абстрагування, системний, формалізації, порівняння та метод моделювання. В результаті проведеного дослідження, автори дійшли висновку, що пошук балансу між публічними та приватними інтересами є у всіх сферах та значною мірою стосується прав людини та, в умовах пандемії, ці правомочності закріплені в головних міжнародно-правових договорах та національних нормативно-правових актах, iз

\footnotetext{
41 Doctor of Legal Sciences, Associate Professor of Department of Economic Law and Procedure of Institute of Law, Taras Shevchenko National University of Kyiv, Ukraine.

${ }^{42} \mathrm{Ph}$. D., Associate Professor of International Law and Comparative Law, International Humanities University, Ukraine.

${ }^{43} \mathrm{Ph}$. D., Associate Professor of Civil Law Department, Taras Shevchenko National University of Kyiv, Ukraine.

${ }^{44} \mathrm{Ph}$. D., Associate Professor of Intellectual Property Department, Taras Shevchenko National University of Kyiv, Ukraine.

${ }^{45}$ Ph. D., Associate Professor of Department of Economic Law and Procedure, National University «Odesa Law Academy», Ukraine.
} 


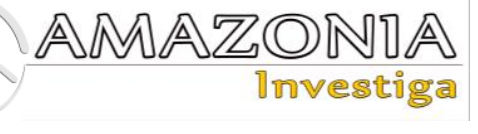

implementation of restrictive measures, proportionality, and public necessity.

Key Words: public interest, private interest, EU law, quarantine restrictions, enforcement, Covid19 pandemic.

\section{Introduction}

In the European Union (hereinafter - EU), the search for effective legal mechanisms for the interaction of state and business (as well as the search for balance and harmonious combination of public and private interests in various spheres of society) continues. To combat the coronavirus, human civilization must mobilize all available resources and develop a common strategy of action, which should be based on a new ethics of relations in the plane of «man-man» and «manstate» (Tkalych, Safonchyk, \& Tolmachevska, 2020). Given this, the study of public and private law as two equal and correspondingly major components of European Union law becomes relevant, especially in the context of Covid-19.

Before considering the public and private interest in European Union law in the context of the Covid-19 pandemic, let us analyze the definitions of these concepts. Private and public law allows you to explore different legal phenomena, and the law itself, from different angles. The public interest consists of the interests of the state, its bodies, and officials, as well as the interests of society, while the private interest is always the interests of individuals; public interest is the interest of the social community recognized by the state and secured by law, the satisfaction of which is a condition and guarantee of its existence and development; everything that concerns the benefits and interests of the community are public, and everything that concerns the benefits and interests of each of its members is private. In this case, the interests of an individual may conflict with the interests of society or the state, but their implementation should not be contrary to the established requirements of law. The interests of society may not coincide with the interests of the individual, which in no way affects the implementation of both the first and the second if such implementation does not contradict the requirements of applicable law. застереженнями щодо можливого їх обмеження за виключних умов. При цьому, забезпечення балансу приватних і публічних інтересів можливе тільки за умов дотримання законності при впровадженні обмежувальних заходів, пропорційності та суспільній необхідності.

Ключові слова: публічний інтерес, приватний інтерес, право СС, карантинні обмеження, забезпечення прав, пандемія Covid-19.

Thus, private interests, the interests of a large part of society (population of the country, territorial community), and the interests of the state can be realized in public relations. The right of a person and a citizen to access justice is one of the fundamental rights, which is not limited even in conditions of martial law and / or state of emergency.

However, new conditions, the introduction of quarantine, and several restrictions have made their adjustments and create challenges for the realization of human rights, including the balance and equilibrium of public and private interests in a pandemic.

With this in mind, the purpose of the analysis is to examine the existing experience of domestic and foreign policies of EU member states to combat COVID-19, taking into account the reaction of the EU, to make recommendations to the Government of Ukraine on additional measures and its consequences.

The object of the study is the private and public interest in EU law in the context of the Covid-19 pandemic. The subject of the study is public relations that arise, change, and cease during the realization of private and public interest in EU law.

Thus, an urgent condition for ensuring human and civil rights and freedoms in Ukraine is to ensure a balance between private and public interests in the context of the Covid-19 pandemic.

\section{Theoretical Framework}

To analyze and study this issue, such scientists and legal practitioners were analyzed as Vdovychenko, Vorotniuk, Gerasymchuk, Koval, and Kraev (2020); Malko and Subochev (2004); 
Nazarchuk (2020); Shtogrin (2020); Nay (2020); Stoyanov (2020); and Yakusha (2020).

Thus, Vdovychenko, Vorotnyuk, Herasymchuk, Koval, and Kraev (2020) analyzed how the balance between private and public interests is maintained in the conditions of the Covid-19 pandemic, and the peculiarities of such interaction in the European Union were clarified.

Malko and Subochev (2004) researched the conceptual and categorical apparatus of the concepts "private interest" and "public interest". Its findings underlie this study to identify key concepts. Thus, the researcher pointed out that the legitimate interest (in contrast to subjective law) is not specifically enshrined in law but only corresponds to it. So, Part 2 of Art. 15 of the Civil Code of Ukraine (Law 435-IV, 2003) stipulates that "every person has the right to protect his interest, which does not contradict the general principles of civil law", the rule of law may protect and consolidate the existence of legitimate interests in general, but not every legitimate interest. Hence, according to the researcher, follows a different degree of guarantee of these institutions.

The UN Human Rights Monitoring Mission has also made a significant contribution to the issue under study. Thus, the Ministry of Culture, Youth and Sports of Ukraine submitted for consideration a bill on disinformation, which considers precautionary measures to combat false information about persons, facts, events, phenomena that did not exist at all or that existed, but information about them is incomplete or distorted. The authors of the project proposed the introduction of strict control over social networks, which provides for the punishment of journalists for disseminating inaccurate information, as well as presented an initiative to establish a special supervisory body - the Commissioner for Information. The project also provided for the introduction of fines, and in some cases - even the possibility of imprisonment. However, the bill has been criticized, with the UN Human Rights Monitoring Mission (United Nations, 2020) disapproving of its position, urging the Ukrainian authorities to refrain from imposing restrictions, as the current bill does not meet international human rights standards.

Nazarchuk (2020) analyzed the peculiarities of the impact of COVID-19 on international law, explored the challenges, tracked trends, and made forecasts. Thus, the author draws attention to the point of view that the fight against a pandemic does not imply the need to deviate from the provisions of the European Convention on Human Rights (United Nations, 1948) (hereinafter - the Convention), has every right to exist. By this logic, the restrictive measures imposed by states can be justified by reference to the possibility of state interference in the exercise of certain rights, which are enshrined in the text of the Convention and repeatedly explained in the case-law of the European Court of Human Rights and the UN Human Rights Committee. The author notes that in the case of the COVID19 pandemic, the European Court of Human Rights (if appropriate) will assess the compliance of the Convention with the measures taken by both the derogating States and those who have remained silent. I doubt that the European Court of Human Rights will be overly formalistic. It is more likely that the justification of the measures taken will be assessed first.

News from Ukraine and the world, USAIDInternews poll "Attitudes of the population to the media and consumption of different types of media in 2019" (Internews, 2019), conference materials "Problems of human rights protection in the information society" (Furashev, \& Petryaev, 2016), publications of lawyers posted on Radio Svoboda (Shtogrin, 2020), News of Ukraine and the world (2020) were also analyzed. For example, a USAID-Internews Media Consumption survey found that trust in all traditional media fell by an average of $11 \%$, compared to 2018. Confidence ranges between $19 \%$ for the national press, $22 \%$ for local radio, and $49 \%$ for national TV channels - while national Internet media are trusted by $51 \%$ of respondents - the highest figure this year (Internews, 2019).

Yakusha (2020) drew attention to the fact that the coronavirus vividly illustrates the role of medicine and who should be the highest value for the state. The author points out that finding a balance between privacy and public health, between individual and collective health, is very difficult, but it should be remembered that any restrictions on human rights that are permissible in certain circumstances must be legal. Article 8 of the Convention for the Protection of Human Rights and Fundamental Freedoms (United Nations, 1950) states that public authorities may not interfere with the exercise of this right, except where the interference is lawful and necessary in a democratic society in the interests of national and public security or the economic well-being of the country, to prevent riots or crimes, to protect health or morals, or to protect the rights and freedoms of others. It was also noted that the 
exercise of the constitutional right to health care, medical assistance, and medical insurance, guaranteed by Article 49 of the Constitution of Ukraine (1996), also came under quarantine. The Resolution of the Cabinet of Ministers of March 11, 2020, No. 211, after amendments to it of March 16, 2020, for the first time enshrines the provision on the temporary suspension of planned measures for hospitalization and planned operations, except for urgent and urgent. At the same time, the Ministry of Health adopted Order No. 698 of March 23, 2020, and established an obligation for health care facilities to temporarily suspend scheduled hospitalizations of patients. Subsequently, Resolution No. 211 (2020) was amended (Resolution No. 239, 2020) and allegedly lifted restrictions on medical practice, but with a caveat - provided that the relevant personnel are accurately equipped, as well as compliance with appropriate sanitary and antiepidemic measures (para. 8 p. 2). However, restrictions on planned medical care and planned hospitalizations remained (paragraph 8). Thus, the author raises the question: what is the purpose of the changes of March 25, 2020, regarding medical practice, if it is still subject to restrictions. Besides, the limitation of constitutional law under Article 49 of the Constitution of Ukraine is permissible only in conditions of martial law or a state of emergency. In addition, foreign articles and publications and primary sources (sites and social networks of international institutions were analyzed: Action Plan against Disinformation. Joint Communication To The European Parliament, The European Council, The Council, The European Economic And Social Committee And The Committee Of The Regions (European Commission, 2019); Code of Practice on Disinformation (European Commission, 2018); «How coronavirus affects human rights» (Amnesty International Ukraine, 2020); Staying Safe During COVID-19: What You Need To Know (Europol, 2020); Coronavirus (COVID19) Information Centre (Organización Mundial de la Salud, 2021); COVID-19 and human rights (Human Rights Watch, 2020).

Thus, the above works contain only general provisions on the balance between public and private interests, but do not specify how such interests are violated in the context of the Covid19 pandemic. Besides, these papers contain only general references to infringements, but do not indicate the causal link that led to such infringements and the role of the balance of interests in that connection. Given the above, it is necessary to conduct a comprehensive study of public and private interests in a pandemic.

\section{Methodology}

In the study of private and public interest in EU law in the context of the Covid-19 pandemic, different scientific research methods were used. Among them: dialectical, historical, idealization, analysis, synthesis, abstraction, system, formalization, comparison, and modeling.

To study the concept of private and public interest in EU law in the context of the Covid-19 pandemic, a dialectical method is used in its relationship and mutual development.

With the method of idealization, it has become possible to construct situations that do not exist for the moment, but which should be provided for a detailed analysis of the interaction of private and public interest in EU law in the context of the Covid-19 pandemic. This will help to draw the correct picture of the possible legal regulation of these legal relations.

The method of formalization is used to study the private and public interest in EU law in the context of the Covid-19 pandemic in a tangible form - through legislation. This method helps to identify inconsistencies, gaps, clashes and conflicts of existing legal norms. Moreover, the historical method makes it possible to explore the development of the concept of human rights, which, in turn, will show whether modern legal norms correspond to the meanings that were put into the concept of "ensuring human rights" in the early stages of development. Besides, the systematic method helps in a comprehensive study the provision of private and public interests in EU law and in Ukraine in the context of the Covid-19 pandemic and its role.

Further, the method of abstraction makes it possible to divert from the understanding of private and public interests in EU law (and national legislation) under modern law and to model qualitatively new proposals for understanding these interests. The generalization method allowed us to explore the typical features of private and public interests in EU law, and, in turn, this makes it possible to see whether the Ukrainian legislator is following the right path in ensuring the balance of private and public interests. The modeling method is used in the process of formulating proposals to the current legislation of Ukraine to ensure a balance 
between private and public interests in EU law in the context of the Covid-19 pandemic.

Finally, the comparison method was used to compare the provision of private and public interests in EU law, in different European countries, and in Ukraine in the circumstances of the Covid-19 pandemic.

\section{Results and Discussion}

\section{European Union pandemic response policy}

There is a lot of research in the international community on the application of international law in emergencies related to catastrophes and armed conflicts; much less - in emergencies caused by epidemics. The foundation for comprehensive international legal regulation in the field of human rights and freedoms, its legitimate interests, and needs is the European Convention for the Protection of Human Rights and Fundamental Freedoms (United Nations, 1950) and 16 additional Protocols adopted over time.

Due to the COVID-19 pandemic, 10 of the 47 member states of the Council of Europe have announced their intention to withdraw from the Convention: Latvia, Romania, Moldova, Armenia, Estonia, Georgia, Albania, Northern Macedonia, Serbia, and San Marino (list updated here). The first "calls" were Latvia and Romania - on March 16 and 18, respectively.

The emergence of the COVID-19 pandemic was unforeseen, but such unpredictability is a significant threat to the European Union. Firstly, it is an urgent crisis in the health care system, which has the potential to provoke a socioeconomic crisis. Secondly, the COVID-19 pandemic calls into question the basic principles of the EU's functioning, in particular, freedom of movement within the Schengen area or solidarity in response to common threats. Thirdly, the ability of the EU institutions to provide timely assistance or at least coordinate Member States' responses in crises is called into question. Fourthly, EU member states' search for individual ways to counter COVID-19 has exacerbated domestic political discussions among Eurosceptics and opened a window of opportunity for other geopolitical players. Ultimately, the crisis has sparked a debate about the EU's vulnerability and the inability to ensure the rights and freedoms of citizens, and even more, the balance between private and public interests (Vdovychenko, Vorotnyuk, Herasymchuk, Koval, \& Kraev, 2020).
The pan-European response to the pandemic is currently limited, partly due to a lack of competence, partly due to the dynamism of the situation, which is difficult for the EU bureaucracy to deal with quickly. However, the EU institutions presented several initiatives to mitigate the effects of the pandemic with economic instruments in mid-March 2020. The focus of such initiatives is on preserving the integrity of the EU single market, providing support to EU citizens and businesses, and identifying rapid response measures to maintain the stability and solidarity of EU Member States.

In addition, the EU Solidarity Fund will henceforth cover the challenges of health emergencies, allowing up to $€ 800$ million to be allocated to the Member States. Given the steady slowdown in economic growth in the eurozone and the EU as a whole, official Brussels is designating $€ 1$ billion to support pandemicaffected businesses. It is also noteworthy that the EU has shown "budgetary flexibility".

\section{Reallocation of the budget due to the pandemic: European experience}

Moreover, states do not react equally to the spread of coronavirus, and quarantine measures are different, as well as measures in terms of social security.

In most EU countries, the volume of anti-crisis programs is in the range of 1 to $2 \%$ of Gross Domestic Product (GDP). Within these funds,

- the French government has earmarked a fiscal package of $€ 45$ billion (about $2 \%$ of GDP) to cover health care costs, tax deferrals, income support for workers and micro-enterprises, rent deferrals, and utility bills for small and medium-sized enterprises;

- in Italy, an emergency package of $€ 25$ billion (1.4\% of GDP), including health care expenditure, income support for laid-off and self-employed workers, and tax deferrals;

- $\quad$ in Spain, an additional budget of $€ 13.9$ billion (1\% of GDP) to support health care expenditures, unemployment benefits, increased hospital payments for infected coronavirus, rent assistance to the poor, and tax deferrals for small and medium-sized businesses;

- $\quad$ in Belgium, a fiscal package of $€$ 8-10 billion (about 2\% of GDP) with measures to increase health care spending, support the income of the temporarily unemployed and the self-employed. Separately, $€ 50$ billion 
(about $10 \%$ of GDP) of guarantees for new bank loans to companies and the selfemployed are provided;

- Germany stands out, which has projected expenditures of almost 5\% of GDP. These include support for additional health care costs, income support for the unemployed or people with limited working hours, tax deferrals, and in some cases, rent and utility bills (Golosnichenko, 2020; Emerson, 2020).

Thus, according to the information provided above, to radically change the course of the pandemic in different countries, it is necessary to pay attention to a whole complex of issues, among which we can single out: explanatory work on the critical importance of vaccination; on the need for social distancing to counter the spread of the virus and comply with other measures; as well as the problem of the proper functioning of the health care system of each country. In this regard, the problem of budgetary financing of various activities aimed at combating coronavirus is of particular importance. Following the example of European countries, the proportional dependence of the volume of budgetary funding and the effectiveness of state policy in the fight against coronavirus becomes obvious.

\section{The problem of disinformation and personal data protection: European experience and Ukraine}

Because the COVID-19 coronavirus pandemic is an international emergency, it affects almost everything, including human rights and freedoms. Quarantine and post-quarantine periods have a great influence on the observance of information culture, moral and ethical norms in social networks and the media. People need to know the truth about the current pandemic situation in the world, and, especially, in their country. There are now misinformers everywhere on the Internet who spread false information about coronavirus or quarantine. The state invests funds and efforts to ensure that the country's citizens receive truthful information from various sources, including social networks. A study of EU initiatives and efforts to counter the spread of fakes, in general, revealed a high level of institutionalization, as well as the speed of response to threats to information security. Among the documents are the Action Plan against Disinformation, developed by the joint efforts of the European Parliament, the European Council, the European Economic and Social
Committee, and the Committee of the Regions, as well as the Code of Practice against Disinformation adopted by the Internet platforms, leading social networks, advertisers and the advertising industry have agreed on a code of practice with the ability to self-regulate to address the spread of misinformation on the Internet.

According to Art. 55 of the Constitution of Ukraine (1996), human and civil rights and freedoms are protected by the court and everyone is guaranteed the right to appeal in court against decisions, actions, or omissions of public authorities, local governments, and officials. Article 64 of the Constitution of Ukraine provides that the constitutional rights and freedoms of man and citizen may not be restricted, except in cases provided by the Constitution of Ukraine. In conditions of martial law or a state of emergency, certain restrictions on rights and freedoms may be established, indicating the term of these restrictions.

Information support for countering the spread of fakes about COVID-19 in Ukraine is largely provided by the Ministry of Health $(\mathrm{MOH})$ of Ukraine. To do this, select information resources are used with daily information on the number of new cases of illness, recovery, death, as well as advice on how to behave in quarantine and its weakening, which have proven their effectiveness. Rebuttal of false information is also implemented. To better inform the citizens, the Ministry of Health of Ukraine publishes this information not only on official websites but also on specially created channels in such messaging services as Telegram and Viber.

Private international companies make a significant contribution to countering fakes about COVID-19. For example, search queries for COVID-19 are answered by Google search engine for advice that has proven effective, information on symptoms of the disease, references to the authorities of many countries (Ministry of Health in the case of Ukraine), and current statistics on the epidemic. Similarly, Facebook has launched a user information campaign called the Coronavirus Information Center (Vdovychenko, Vorotnyuk, Herasymchuk, Koval, \& Kraev, 2020), which also publishes the latest news and current data on the epidemic.

At the initial stage of the spread of coronavirus infection in Ukraine, some media outlets managed to publish fake reports about the 
whereabouts of people who are allegedly sick with Covid-19 or about whom there is reasonable suspicion. It is clear that such actions have nothing to do with anti-epidemic measures or ensuring the public interest, but here it is necessary to pay attention to the law (Kozub, 2020).

In the context of a global coronavirus pandemic, quarantine was introduced following the resolution of the Cabinet of Ministers of Ukraine (2020). During this period, the issue of protection and use of personal data, which can be used to combat the spread of the disease, became significant. The information legislation of Ukraine regulates the rights of citizens to collect, receive, use and disseminate information. Besides, information legislation sets requirements for the processing of personal data. According to Art. 7 of the Law of Ukraine "On Personal Data Protection" (Law No. 2297-VI, 2010) prohibits the processing of personal data on the health of a person without his/her consent. However, in the event of an emergency, such as the COVID-19 pandemic, the government may decide to change the law, as happened during the quarantine period.

On April 13, 2020, the Law on Prevention of the Spread of Coronavirus Disease (COVID-19) (Law 555-IX, 2020) was adopted, which allowed, in particular, treatment personal data without the consent of the person. The authorities' actions were aimed at obtaining as much data as possible on patients with COVID19 to, with this information, implement as effectively as possible measures to curb the spread of the disease. In particular, it concerned data on the state of health, place of hospitalization, place of residence, and work of a person - data on places, where the patient spent a lot of time before hospitalization. Thus, it is possible to take efficient preventive measures, for example, by testing for COVID-19 among visitors to frequent patients before hospitalization.

\section{State policy of Ukraine in the field of maintaining a balance between private and public interests}

Regarding quarantine changes in the field of labor law, it can be noted that during the quarantine the employment contract between the employee and the employer continues to operate, and dismissal at the initiative of the employer is possible, but only on the grounds provided by Articles 40 and 41 of the Labor Code of Ukraine (Law No. 322-VIII, 1971). In this case, the employer is obliged to provide some guarantees provided to the employee by the current legislation on dismissal, such as Articles 147-149 of the Labor Code (Yarovyi, 2020).

We share the opinion that such modifications are a positive factor in maintaining a balance of public and private interests in quarantine.

However, there remains another major issue related to the allocation of costs for counteracting the spread of coronavirus disease. It is no secret that, for example, in the United States, the public closely monitors which programs are spent on taxpayers. In contrast, Ukrainian citizens do not seem to care much about whether their money will be used to build roads or to fight the coronavirus, or perhaps to co-finance law enforcement. Thus, the real problem that the Ukrainian economy and Ukrainian society will inevitably face is the consequences of the pandemic. An additional burden to fight the coronavirus is that our state has resorted to borrowing new loans from such partners as the European Union, the European Bank for Reconstruction and Development, the International Monetary Fund, and others. That is, it is also about increasing the debt of our state, which will ultimately fall on the shoulders of the real sector of the economy. Therefore, it is worth considering whether the balance of private and public interests is observed in this way, because it may happen that we will also face misuse of the coronavirus fund, which has already happened in our history.

And here it could be noted that the necessary mechanisms for monitoring, financial control over the distribution of money from this fund or, for example, involving the media in covering this issue, but if the problem is the indifference of taxpayers themselves, a set of measures to raise awareness of civil liability, including the implementation of their interests, goes far beyond the usual financial monitoring. Moreover, data on the distribution of budget funds, in particular, from the coronavirus fund, is not so difficult to find on the Internet. Thus, in this aspect, the issue of maintaining a balance of public and private interests may make sense at least provided that it is of interest to the citizens of Ukraine.

In the context of ensuring the balance of private and public interests, another aspect is also important. It should be noted that the covid-19 pandemic has some positive aspects, paradoxically. We are talking about reducing carbon emissions and improving the 
environmental situation almost all over the planet due to quarantine measures. Restrictions on a number of human rights, including the right to free movement, the right to work, the right to entrepreneurial activity and others, introduced to ensure the public interest, are certainly a negative factor. However, the consequence of quarantine restrictions is, in particular, the improvement of the environmental situation in the world and, to some extent, indirectly, ensuring people's right to a clean environment. Thus, albeit involuntarily, a certain balance is achieved between the provision of private and public interests during the introduction of restrictive measures.

\section{Conclusions}

1. A coronavirus pandemic can be considered one of the conditions under international and national law, as it poses a significant threat to the life and health of the population, its welfare, and democracy, etc., as a result of which the introduction of quarantine measures under the influence of coronavirus will be considered legal human rights, with the exclusion of statutory exceptions to such restrictions.

2. Public disclosure of personal data of patients with coronavirus, contact persons, etc. is a violation of the conventional and constitutional human right to privacy and protection of personal data, despite legal restrictions. In the context of the Covis-19 pandemic, this poses a particular threat to the lives and well-being of individuals, as it leads to their stigmatization, harassment, intimidation, harassment, and physical violence against them. From this point of view, it is necessary to do everything possible to effectively apply a detailed mechanism for collecting and processing personal data of relevant persons, which in practice will mean compliance with the principle of legal certainty in implementing such algorithms, establishing an exhaustive list of data collection and processing.

3. Ensuring the balance of private and public interests is possible only if the rule of law is in the implementation of restrictive measures. Thus, individuals will not abuse their rights, and the interests of society or the state will not have a priority that would violate the rights of human and citizen. This legal configuration, as part of the social contract, is implemented in the form of law as a source of legal regulation.

4. Restrictions on the constitutional rights and freedoms of man and citizen can be justified only if three criteria are met: legality, proportionality, and social necessity.

5. The allocation of budget funds and the government's new debt obligations under the influence of the spread of coronavirus disease should become a painful issue for taxpayers and the real sector of the economy in the foreseeable future. Misuse of funds raised to counter Covid-19 clearly cannot be justified without the approval of the taxpayers themselves, as this would violate their interests.

\section{Bibliographic references}

Amnesty International Ukraine. (February 6, 2020). «How coronavirus affects human rights». Recovered from www.amnesty.org.ua/koronavirus-i-pravalyudyny

Emerson, M. (2020). The virus as a challenge to unity: what will be the EU's anti-crisis strategy. Center for European policy research. Recovered from

https://www.eurointegration.com.ua/experts/202 0/04/9/7108539.

European Commission. (2018). Code of Practice on Disinformation. Recovered from https://ec.europa.eu/digital-single-

market/en/news/code-practice-disinformation European Commission. (2019). Action Plan against Disinformation. Joint Communication To The European Parliament, The European Council, The Council, The European Economic And Social Committee And The Committee Of The Regions: Report on the implementation of the Action Plan Against Disinformation. Recovered from https://eur-lex.europa.eu/legalcontent/EN/TXT/?uri=CELEX\%3A52019JC00 12.

Europol. (November 12, 2020). Staying Safe During COVID-19: What You Need to Know. Recovered from https://www.europol.europa.eu/staying-safeduring-covid-19-what-you-need-to-know Furashev, V.M., \& Petryaev, S. Yu. (Eds.). (2016). Problems of human rights protection in the information society. Kyiv: National Institute for Strategic Studies, Secretariat of the Ukrainian Parliament Commissioner for Human Rights. Golosnichenko, D.I. (2020). Social security of citizens in the conditions of coronavirus. Legal Life of Modern Ukraine, 2, 162-165. Recovered from

http://dspace.onua.edu.ua/bitstream/handle/1130 0/12624/\%D0\%9F\%D1\%80\%D0\%B0\%D0\%B 2\%D0\%BE\%D0\%B2\%D0\%B5\%20\%D0\%B6 $\% \mathrm{D} 0 \% \mathrm{~B} 8 \% \mathrm{D} 1 \% 82 \% \mathrm{D} 1 \% 82 \% \mathrm{D} 1 \% 8 \mathrm{~F} \% 20 \% \mathrm{D}$ 
$1 \% 81 \% \mathrm{D} 1 \% 83 \% \mathrm{D} 1 \% 87 \% \mathrm{D} 0 \% \mathrm{~B} 0 \% \mathrm{D} 1 \% 81 \%$ D0\%BD\%D0\%BE\%D1\%97\%20\%D0\%A3\%D 0\%BA\%D1\%80\%D0\%B0\%D1\%97\%D0\%BD $\% \mathrm{D} 0 \% \mathrm{~B} 8 \% 2 \mathrm{C} \% 202020 \% 20 \% \mathrm{D} 1 \% 80 . \% 2 \mathrm{C} \% 2$ 0\%D0\%A2\%D0\%BE\%D0\%BC\%202.pdf?sequ ence $=1 \&$ is Allowed $=\mathrm{y}$.

Human Rights Watch. (April 1, 2020). «COVID-19 and human rights». Recovered from www.hrw.org/ru/news/2020/04/01/340211

Internews. (2019). Online media and social networks have taken the lead in television in popularity in Ukraine - a new USAID-Internews poll on media consumption. Recovered from https://internews.in.ua/uk/news/onlajn-media-tasotsialni-merezhi-perehopyly-liderstvo-utelebachennya-za-populyarnistyu-v-ukrajininove-opytuvannya-usaid-internews-schodospozhyvannya-zmi/

Kozub, T. (2020). Where Covid-19 was recorded in Kyiv. Vesti publishes streets and house numbers. Vesti. Recovered from https://vesti.ua/people/gde-v-kieve-zafiksirovancovid-19-vesti-publikuyut-ulitsy-i-nomeradomov.

Law No. 2297-VI, On Personal Data Protection. Bulletin of the Verkhovna Rada of Ukraine, Kyiv, Ukraine, June 1, 2010. Recovered from https://zakon.rada.gov.ua/laws/show/2297-

17\#Text.

Law No. 254к/96-BP, Constitution of Ukraine. Bulletin of the Verkhovna Rada of Ukraine, Kyiv, Ukraine, June 28, 1996. Recovered from https://zakon.rada.gov.ua/laws/show/254\%D0\% BA/96-\%D0\%B2\%D1\%80\#Text.

Law No. 322-VIII, Labor Code of Ukraine. Bulletin of the Verkhovna Rada of Ukraine, Kyiv, Ukraine, December 10, 1971. Recovered from https://zakon.rada.gov.ua/laws/show/32208/conv\#n17.

Law No. 435-IV, Civil Code of Ukraine. Bulletin of the Verkhovna Rada of Ukraine, Kyiv, Ukraine, January 16, 2003. Recovered from https://zakon.rada.gov.ua/laws/show/435-

$15 \#$ Text.

Law No. 555-IX, On Amendments to the Law of Ukraine "On Protection of the Population from Infectious Diseases" on Prevention of the Spread of Coronavirus Disease (Covid-19). Bulletin of the Verkhovna Rada of Ukraine, Kyiv, Ukraine, April 13, 2020. Recovered from https://zakon.rada.gov.ua/laws/show/555-20.

Malko, A. V., \& Subochev, V. V. (2004). Legitimate interests as a legal category. St. Petersburg: Legal Center Press.

Nay, O. (2020). Can a virus undermine human rights? Lancet Public Health, 5(5), 238-239. doi: 10.1016/S2468-2667(20)30092-X

Nazarchuk, I. (April 16, 2020). The impact of COVID-19 on international law. Lawyers analyze challenges, track trends, make forecasts (part one). Radio Liberty website. Recovered from

https://www.radiosvoboda.org/a/coronavirusmizhnarodne-pravo/30555879.html

News of Ukraine and the world. (March 27, 2020). Fraud, theft and forgery. Europol has reported an increase in coronavirus-related crimes. Recovered from https://nv.ua/ukr/world/geopolitics/koronavirusvidi-shahraystva-pid-chas-pandemiji-ostanninovini-50078304.html\

Organización Mundial de la Salud. (2021). Coronavirus (COVID-19) Information Centre. Facebook. Recovered from https://www.facebook.com/coronavirus_info Resolution No. 211. On prevention of the spread on the territory of Ukraine of the acute respiratory disease Covid-19 caused by the coronavirus SARS-CoV-2. Bulletin of the Verkhovna Rada of Ukraine, Kyiv, Ukraine, March 11, 2020. Recovered from https://zakon.rada.gov.ua/laws/show/211-2020$\% \mathrm{D} 0 \% \mathrm{BF}$

Resolution No. 239. Bulletin of the Verkhovna Rada of Ukraine, Kyiv, Ukraine, March 25, 2020. Recovered from https://zakon.rada.gov.ua/laws/show/239-2020$\%$ D0\%BF\#Text.

Shtogrin, I. (2020). The coronavirus pandemic: lessons for humanity and Ukraine. Radio Svoboda. Recovered from https://www.radiosvoboda.org/a/pandemiyakoronaviruskarantyn-vysnovky/30500165.html Stoyanov, A. (April 1, 2020). The European Commission's Fight Against Coronavirus Disinformation. The Mayor. Recovered from https://www.themayor.eu/fr/a/view/theeuropean-commission-s-fight-againstcoronavirus-disinformation-4688 Tkalych, M., Safonchyk, O., \& Tolmachevska, Y. (2020). Private Law and human rights: New realities. DIXI, 32, 1-12. DOI: https://doi.org/10.16925/2357-5891.2020.02.04 United Nations. (1948). Universal Declaration of Human Rights. Recovered from https://www.un.org/en/universal-declarationhuman-rights/.

United Nations. (1950). Convention for the Protection of Human Rights and Fundamental Freedoms. Recovered from https://www.echr.coe.int/documents/convention _eng.pdf

United Nations. (2020). Human Rights Monitoring Mission in Ukraine. Recovered from https://www.ohchr.org/en/countries/enacaregion /pages/uaindex.aspx

Vdovychenko, V., Vorotnyuk, M., Herasymchuk, S., Koval N., \& Kraev, O. (2020). 
The EU covid-19 pandemic: selfishness, solidarity or spreading influence? Ukrainian Prism Foreign Policy Council. Recovered from http://prismua.org/wpcontent/uploads/2020/05/COVID19EU.pdf Yakusha, V. (2020). Chairman of the NAAU Committee on Medical Law Iryna Senyuta: "Coronavirus vividly illustrates the role of medicine and who should be the highest value for the state." Law and Business, 16, 14-70. Recovered from https://zib.com.ua/ua/142409koronavirus_yaskravo_ilyustrue_rol_medicini_i _te_hto_mae_but.html

Yarovy, A. (2020). Violations of human rights during a pandemic: where is the limit? LB.ua. Recovered from https://lb.ua/blog/anatolii_yarovyi/453463_poru shennya_prav_lyudini_pid_chas.html 